\title{
A CHARMING GERMAN IN THE JAWS OF AMERICAN POLITICS US Influence on Willy Brandt's Political Profiling and Eastern Politics
}

Keywords:

Willy Brandt; United

States; Eastern politics; John F. Kennedy; Richard

Nixon; Henry Kissinger

Author:

Dr. Slavojka Beštić-Bronza is an Assistant Professor at the Faculty of Philosophy of the University of Banja Luka

Correspondence:

slavojka.bestic-bronza@ ff.unibl.org

Field:

General history

\section{Summary}

The aim of this paper is to show to what extent and by what mechanisms the United States influenced the political formation of the personality and activities of West German Chancellor Willy Brandt. Special emphasis was placed on American influences during the implementation of Brandt's most famous political concept, 'Eastern Politics', which provides the chronological context of the development of relations in line with pan-European and world political movements and their correlation with Brandt's political path in exile and later in occupied Germany, and, finally, in the newly created independent Federal Republic of Germany. Circumstances, personal (dis)inclinations, and mutual influences gave birth to a rather ambivalent relationship, created mainly due to the interests of both parties, which overlapped in certain periods of time, while later they moved away and became cold, even often hostile.

DOI:

10.5937/politeia0-26956

Paper received on:

21.03.2020.

Paper accepted for publishing on:

07.06.2020 


\section{INTRODUCTION}

The life and political career of the famous German politician Willy Brandt (1913-1992) was the focal point of many books, scientific and journalistic works, biographies and autobiographies, but to this day, 28 years after his death, it has remained mysterious, intriguing and vague in many respects. Many "gray zones" of his life are still fascinating, so it is not surprising that not only scientists of various backgrounds pay attention to him, but also journalists eager for sensationalism, former intelligence agents eager for public appearances after decades of working in the shadows, and his political allies and opponents.

Given the fact that at a very young age in his native Lübeck he began to engage in politics at a turbulent time of political turmoil in Weimar Germany, and that he went through life stages of emigration, like the return to devastated Germany, ups and downs in his political and private life, it is logical that his political attitudes and beliefs changed, modified and adapted to the circumstances and personalities to which he was referred. One of the most interesting and complex relationships was Brandt's relationship with various aspects of American influence and politics. The collaboration arose out of necessity, in some stages it was even overly enthusiastic and cordial, while in others it was overly rigid and cold. The period that Brandt spent as German Chancellor (1969-1974) and when he implemented Eastern politics in full glory, gives a finely nuanced picture of this, in many ways, strange symbiosis.

German Chancellor Willy Brandt's Eastern policy (“Ostpolitik”) $)^{1}$ was aimed

1 A more precise name would be "New Eastern Policy" to emphasise the distinction in West German policy of refusing cooperation with East Germany, during the period of domination of the Christian Democratic at solving problems in Central and Eastern Europe through a direct, i.e. much more independent policy of cooperation between the Federal Republic of Germany and the USSR and other Warsaw Pact countries. However, the attitudes of the Western allies had a significant dimension in the implementation of Eastern policy for Brandt and the West German political leadership.

Throughout the period of Brandt's diplomatic activity, the difficulties were not only the solid isolationist walls he often encountered in the East, but also the suspicious and admonishing views to which he was exposed from the West. It was another inevitable remnant of the legacy of World War II, i.e. the fact that FR Germany, as a defeated country in the war, although firmly involved in Euro-Atlantic integration, had to accept the role of limited responsibility and field of action, i.e. work strictly according to the will of its political more powerful allies within the NATO pact, the United States, Great Britain and France.

The first decades after World War II represented a great weakening of Great Britain's political and economic power in international relations. Therefore, it could not influence the development of West German politics to the same extent as the United States, a country which after the Second World War, became an untouchable flagship of the Western world, and thus the most influential power in Western Europe, and even in West Germany. Great Britain's role was diminished even in comparison with France, who nevertheless possessed the power to become the dominant political force among European states,

Union and Chancellor Konrad Adenauer (1949-1969). One of the important steps of the New East Policy was the deviation from the Hallstein Doctrine, which proclaimed the abolition of diplomatic relations with the countries that recognised East Germany and established diplomatic relations with it. 
and the only one, at least to some extent, to pursue a policy that was independent of the United States. Thus, Brandt's Eastern policy from 1969 to 1974 was much more exposed to the influences of the United States and France than Great Britain.

\section{WILLY BRANDT AND THE UNITED STATES UNTIL 1969}

Unlike Western European countries and the USSR, whose political systems played a significant role in the development of Brandt's political aspirations, the influence of the United States and its democracy on Willy Brandt during his youth was not particularly significant. The fact is that American democracy has never had much to do with classical European social democracy, with which Brandt grew up in his native Lübeck. Therefore, from a young age, Brandt saw the United States as the main bearer of the ideology of big capitalism, which was not particularly close to him, so he never saw that country as a model. These views from his youth evolved to a lesser extent during his exile in Norway and Sweden, ${ }^{2}$ from an ideological point of view, but overall, they remained firmly rooted throughout his life.

Many years of living in countries that cultivated a specific type of Scandinavian democracy, significantly influenced Brandt's political education and made him much more pragmatic and flexible than he was in his youth, so he cooperated with the Americans in Sweden and accepted American help upon his return to Germany after the war, to advance in the political framework of the new Germany. In addition to building ideological discourses toward U.S. policy before the end

2 Interesting are his positive thoughts and ideas about the policy of the New Deal of US President Franklin D. Roosevelt, when, erroneously, he considered it ideologically close to European social democracy (Michel, 2010: 69). of World War II, Brandt built his American ties in two practical directions. First, he referred to the fact that his political mentor, Jakob Walcher, one of the leaders of the SAP, the party to which Brandt belonged from 1931 to 1944, was in New York in the early 1940's (Merseburger, 2002: 215216). After the transition from occupied Norway to neutral Sweden, at the end of June 1940, it quickly became clear that the situation was not particularly favourable for Brandt in that country either, because there were serious threats that, as a German politician and emigrant, he could have been deported to Germany by the Swedish authorities. That is why he increasingly thought about traveling to a safer place, that is, to the United States. In February 1941, he re-established contact with his political mentor, Walcher, through letters. However, in time he gave up traveling to the United States, and decided to stay in Sweden, regardless of the risk (Brandt, 1982: 388).

The second type of cooperation was related to cooperation and friendship with the American journalist John Scott. In Stockholm, Brandt, first indirectly through Scott, and later directly, cooperated with the American secret service Office of Strategic Services (OSS). Over time, confidence in Brandt's reporting and analysis grew, and from the fall of 1944, Brandt submitted his reports directly to various topics related to the situation in Norway and the Swedish American mission in Stockholm and to envoy Herschel Johnson, who forwarded them to Washington. In these reports, Brandt put forward proposals that allied forces could organise a democratic society in Germany after the war. One of the OSS agents and also Herschel Johnson himself praised Brandt and envisioned him to play an important role in the rebuilding of a democratic Germany. In these articles, it was very important for Brandt to show that there are Germans and a Germany different from the Nazi one (Michel, 2010: 40-44). Brandt's 
openness for cooperation with the Americans in postwar Germany fitted with his increasingly pronounced and articulated anti-communism, which he strengthened by facing the first experiences of repressive Stalinism in the form of intervention in Czechoslovakia in 1948 and the First Berlin Crisis of 1948-49 (Michel, 2010: 72).

\section{MELTING POINT - BERLIN}

After the war, Americans and their politics became much more present in Germany, so that was a big change for the otherwise Eurocentric Brandt. Over time, he collaborated more and more with them, especially in Berlin, which, after returning from emigration and regaining German citizenship (1948), became the main place for the development of his political career. In the atmosphere of a besieged West Berlin, Brandt's cooperation with the Americans and other Western allies was very efficient and cordial, which was already evident during the blockade of Berlin in 1948 and 1949 and its survival thanks to the "Air Bridge", a brilliant idea and a daring endeavour, by General Lucius D. Clay, who kept Berlin and Berliners alive and metaphorically promoted Berlin to the "cradle of German-American friendship" (Brandt, 1992: 15).

In the following years, Brandt, as a member of the SPD, but even more as a citizen and functionary of West Berlin, ${ }^{3}$ was oriented to work closely with the Americans, mainly because West Berlin evolved into military enclave in the communist world and therefore Brandt was thankful for the military presence of the Americans, British and French. Brandt also owed them his political rise in the party hierarchy and inter-factional struggles within

3 First as a close associate of Ernst Reuter, the mayor of West Berlin, and then as the mayor himself (19571966). the SPD. Seen from an American perspective, he was a "young, dynamic, imaginative, personable, forceful man, who spoke beautiful English, a fitting successor to Reuter"4 (CIA-RDP80B01676R003200180020-8) without a burdensome past. And with a political approach nicely packaged in Scandinavian openness and pragmatism, combined with already adopted characteristics of democratic liberalism, he was a perfect candidate for cooperation with representatives of the American occupation authorities in Berlin and the implementation of democratic and anti-communist ideas in the period of re-education of German society, especially because of his political fixation on problematic Berlin. The cooperation was mutually beneficial. The Americans gained a reliable collaborator, while Brandt progressed and became more and more popular in the ranks of the SPD, although political opponents accused him of being the leader of the "American faction" (Brandt, 1992: 20).

American support took place in various ways, Brandt became the link between the German administration in Berlin and the Americans, first through the left liberal organisation (Americans for Democratic Action, ADA), led by later US Vice President Hubert Humphrey, through which his articles on the situation in Berlin came to the American public. Over time, he also had more and more contacts with representatives of the American Congress who were interested in Berlin and intended to visit the city.

From 1947, he was a regular actor in the Berlin social life and in socialising with Ame-

4 Significant is the assessment of Brandt's personality by the commissioner of the American president Eisenhower, James M. Lambie, who met with Brandt on November 4, 1957, during his stay in Germany as part of a CIA-backed campaign, document number CIA-RDP80B01676R003200180020-8 (November 4, 1957). For release on July 29, 2003. Visited March 12, 2020, URL: https://archive.org/details/cia-collection) 
rican and British representatives who worked in the Allied military administration in Berlin, to whom he presented the views of the SPD on various issues related to Berlin (Michel, 2010: 79-80). Brandt cooperated with the Americans in various spheres, especially through the RIAS (Radio Broadcasting in the American Sector), to which he later acknowledged the development of new social values based on the achievements of Western democracy and dealing with a painful past without pressure on the Germans. In addition, Brandt collaborated with the Congress for Cultural Freedom (CCF), which was founded and funded by the CIA, with the aim of supporting the fight against the spread of communist ideas by promoting democratic cultural achievements. Brandt was chairman of the German executive committee (committee) inside the Congress, an organisation that published "The Month" ("Der Monat"), a newspaper in which Brandt also published his articles (Michel, 2010: 81-83). Financial assistance to Brandt and associates came from behind-the-scenes transactions by the High Commission for Occupied Germany (HICOG), which included the renting of advertisements for promoting of the Marshall Plan at extremely high prices $(200,000 \text { German marks })^{5}$ in the Berliner "Stadtblatt" newspaper, which was edited by Brandt between 1949 and 1951 (Krause, 2015: 79-99).

Unlike many colleagues from the SPD, Brandt was a strong supporter of the American making of ties within Euro-Atlantic integration as strong as possible, and he did not doubt the need for FR Germany to join NATO in 1955. He believed that the concept of collective security advocated by Erich Ollenhauer and other SPD leaders at the time, according to whom, in fact, all world countries should have been united in a single military-political

5 The real price of the ad was incomparably lower, so the difference in money went to finance party activities and promotions. bloc, was impossible and unproductive in a situation of total confrontation with the USSR (Merseburger, 2002: 311). Brandt, however, advocated the possibility of Germany's withdrawal from NATO, if the possibility of unification with the German Democratic Republic (East Germany) arose. He considered that the possibility of "liberating" 18 million Germans from the Soviet ring and their reintegration into the Western system of life was much more useful for the whole West than the 12 divisions with which it was conceived that FR Germany would participate in NATO joint forces ${ }^{6}$ (Merseburger, 2002: 322). Adenauer and his CDU/CSU Union, however, believed that NATO, i.e. the fact that the Federal Republic of Germany was in it, would be a crucial means of putting pressure on the leadership of the German Democratic Republic to start unification negotiations (Merseburger, 2002: 311).

When he became the mayor of Berlin, cooperation with the Americans was even more important for Brandt, and the Americans were increasingly inclined to the new German politician (Kissinger, 1999: 536). During a trip to the United States in February 1958, Brandt was hailed and presented as "a young man with a bright future in German politics." He met with President Dwight Eisenhower, his deputy Richard Nixon, and Foreign Secretary John Foster Dulles. He received the first of his many honorary doctorates in Philadelphia. He then visited the UK, where he met with Prime Minister Harold McMillan. From the Americans and the British, Brandt received their guarantees for West Berlin, that is, a promise that these two powers would continue to advocate the survival of West Berlin, as a democratic enc-

$6 \ldots$ die Freisetzung von 18 Millionen unserer Menschen würde auch für die Sicherheit der westlichen Welt mehr bedeuten... als 12 westdeutsche Divisionen.“ (Merseburger, 2002: 332) 
lave in a communist environment, but such guarantees still meant nothing concrete for the determining of the city's final future (Merseburger, 2002: 349-350).

Meanwhile, Brandt's reputation continued to grow on the West German political scene. At the SPD congress in Hanover, at the end of November 1960, Brandt was elected as the party's candidate in the elections for chancellor in the following year (Merseburger, 2002: 382). In order to improve his chances in the elections, Brandt tried to show that he has great support of American politics. As early as 1961, he visited US President John F. Kennedy for the first time (Münkel, 2004: 11). This visit did not bring any more concrete results, but it had a distinct propaganda significance (Merseburger, 2002: 387). Although the United States, objectively, under President Dwight Eisenhower never lost its primacy in technology, military power, and industry, due to the successful Soviet launch of Sputnik in 1957 and other, more or less successful, Soviet propaganda offensives, the United States was under the huge influence of a certain defeatism. In that atmosphere, the arrival of Kennedy at the helm of the country, at the beginning of 1961, seemed like a new renaissance of the USA. Kennedy was the bearer of a fresh spirit in almost all aspects of American life (Münkel, 2004: 13).

The situation in Germany was not such in terms of defeatism, but the SPD nevertheless hoped that the Germans would recognise similar values in Brandt, and began to play the card of Adenauer's age, that is, Brandt's freshness and innovation in comparison with the old ruling chancellor (Merseburger, 2002: 389). However, that did not help Brandt, so he was defeated in the 1961 elections, although in the meantime he experienced a new wave of popularity, during the crisis over the construction of the Berlin Wall (Münkel, 2004:
14). The fact that the Western powers did not do anything on the very day of the beginning of the construction of the wall, August 13, 1961, was very important for the further relationship between Brandt and American politicians. The future West German Chancellor did not forget that on this very date Kennedy, McMillan, and de Gaulle enjoyed yachting, hunting, and their country estates (Merseburger, 2002: 396).

There is a certain amount of bitterness finely diplomatically packaged in Brandt's autobiography "My Life in Politics", due to American hesitation, short-sightedness and misunderstanding of the importance of Berlin, and giving the Soviets a dominant role in liberating the German capital. In his autobiography, Brandt did not fail to mention that in the last weeks and days of World War II in Europe, the Western Allies did not look at Berlin any differently than as yet another point on the topographic military map, without thinking about the symbolic significance of Berlin for Germans and other European nations, which later was acknowledged even by US President Dwight Eisenhower (Brandt, 1992: 13-14).

After the end of the elections in 1961, there was a small stalemate in Brandt's political career, so his relations with American politicians became less relevant. However, over time, the position of the CDU weakened more and more, so the Union was forced to enter into a coalition with the SPD in 1966, in order to form a new government of "Grand Coalition" without elections (Göbel, 1996: 114). Inside that government, the chancellor was Kurt Kiesinger, while Brandt was given the most important position in his political career thus far - the position of Minister of Foreign Affairs (Görtemaker, 1999: 437). This was followed by a move to Bonn, the definitive cessation of the role of mayor of Berlin, and the opening of opportunities for the development of new dimensions of Brandt's 
cooperation with the United States (Kissinger, 1981: 107; Merseburger, 2002: 487).

The Americans were pleased with the fact that Brandt initially pointed out that his role model among his predecessors in the position of German Foreign Minister was Gustav Stresemann (Merseburger, 2002: 494), because this politician from the Weimar Republic was the embodiment of Germany's Western and democratic aspirations.

At first it seemed that the government of the Grand Coalition would be difficult to function, but it soon proved itself in the best possible light (Kissinger, 1981: 107). FR Germany gained new economic momentum, and the government of the Grand Coalition, led by Kurt Kiesinger (1966-1969), according to its results, very soon proved to be one of the best in the entire German history, in fact better even than the governments that Brandt compiled when he came to the helm of FR Germany in 1969. However, for the new German Minister of Foreign Affairs, the foreign policy problems were much more significant. At the beginning of his diplomatic career, he faced the biggest dilemma of West German politics after the Second World War - whether to build a key alliance with France or with the United States (Merseburger, 2002: 501).

The United States was already deeply involved in the Vietnam War at the time. As early as 1967, the Americans had over 500,000 soldiers there (Kissinger, 1999: 598), and they strived to achieve a "pax atomica" with the USSR, and to secure the full support of the Federal Republic of Germany. Brandt traveled to Washington in February 1967. He had known US President Lyndon B. Johnson from before, as well as the Secretary of State Dean Rusk. The Americans demanded that the Germans get directly involved in the Vietnam War. However, Brandt limited himself to the sending of the German hospital ship "Helgo- land" into Vietnamese waters (Merseburger, 2002: 502).

It was the beginning of a new stage in the relations between FR Germany and the USA, in which Brandt tried to show the Americans that he had no intention of blindly following them in everything and everywhere. Back in October 1969, just before Brandt was elected as chancellor, Egon Barr told Henry Kissinger that relations between the United States and all other countries and Willy Brandt, as West German chancellor, would be completely different from the relations to which the victorious powers were accustomed in previous contacts with West German politicians. At least at the time, he emphasised that Brandt, unlike his predecessors, had no guilt, and that he did not consider himself a representative of a defeated, but of a liberated Germany. Of course, he explained this by Brandts emigration past (Bahr, 1996: 240).

\section{US ATTITUDES TOWARD BRANDT'S POLICY IN THE EAST}

A significant factor in the setting of the United States towards Brandt's Eastern policy in 1970, as in the following years, was the American engagement in the Vietnam war. On the other hand, Brandt's peace initiatives could significantly benefit the United States and other Western allies, as a means of preventing possible new pressures of the Warsaw Pact in Europe. Nevertheless, the West was significantly surprised by the speed with which Brandt reached agreements with the USSR and Poland in 1970. The Western allies, above all the United States and France, were not particularly sympathetic to the rapprochement between Brandt and Brezhnev. However, they were not allowed to act openly against guidelines that were based on peacekeeping efforts. The peak of Bran- 
dt's fame and triumph over other Western political counterparts came in October 1971, when Brandt was awarded the Nobel Peace Prize in Oslo (Merseburger, 2002: 639). It was the culmination of Brandt's political career. In just two years since taking over the helm of FR Germany, Brandt had become the most popular Western politician in the world. That was the reason Americans devoted themselves to him to a much greater extent.

The US Secretary of State, Henry Kissinger, had great concerns about the development of the German Chancellor's Eastern policy (Seebacher, 2006: 265). He was not so much afraid that FR Germany, through the success of that policy and his new position between the West and the East, would somehow break away from the West and its control. But he feared that Brandt himself would eventually lose control of the whole situation, and, moreover, that Brandt's policy, when one day pursued by less conscientious German politicians, would grow into a new explosion of German nationalism, which would be reflected in the aspiration to achieve a completely independent position of Germany in relation to both West and East (Kissinger, 1981: 441).

Kissinger also considered Egon Barr, one of the co-creators of Eastern politics, to be a classic German nationalist whose feelings towards the United States and the unity of the West were rather unimportant, or much less important than in the cases of previous German politicians. In that sense, Kissinger did not care about Bar's great education and high intelligence, or his bravura handling of diplomatic compromises, from which the entire West benefited greatly. However, Kissinger basically knew what difficulties Brandt and his associates had to deal with. He knew that the continuation of the old policy (Hallstein's doctrine) of FR Germany lead to further isolation from the East, and to the line of fierce confrontation and possible armed conflicts. That is why Kissinger concluded that Brandt's "historical merit" was that he took on all the difficulties that arose from the historical position of West Germany, so he decided to cooperate with him (Merseburger, 2002: 623).

Yet American policy toward Brandt and his efforts was never entirely honest. Americans often sought to attribute the general easing of tensions within the Cold War in the early 1970 s solely to themselves. So Kissinger arrogantly stated in a conversation with Brandt: "Well, well, if we need to ease the tension, we will do it, but we will take care of it, not you." (Merseburger, 2002: 623), ${ }^{7}$ emphasising the crucial role of the United States in all matters relating to relations with the USSR.

Kissinger's skepticism towards Brandt was greatly surpassed by the skepticism of US President Nixon. From the beginning to the end he was distrustful of Brandt's moves in the East. What Kissinger was secretly afraid of, was already a half-realised scenario with Nixon. He was convinced that Brandt was embarking on an open break with the United States and the West (Kissinger, 1981: 443). That is why he cynically warned Brandt: "Don't give up on old friends before you are completely sure that you have new ones that you can rely on" (Merseburger, 2002: 624). As a prominent representative of conservative American Republicans, Nixon hated the left, and therefore considered Brandt to be another "damned socialist" (Merseburger, 2002: 624).

Prior to Brandt's visit to the United States in June 1971, Nixon told American politicians in the White House, "Dear God, if [Brandt]

7 „Wenn schon Entspannung, dann machen wir sie." (Merseburger, 2002: 623). However, Peter Bender, transmits even more precisely: „Na gut, schön. Aber das eine sage ich Ihnen: wenn Entspannungspolitik, dann machen wir sie und nicht Sie." (Bender, 1995: 187) 
is Germany's greatest hope, then there really isn't much hope for Germany." (Merseburger, 2002: 626). He added that he would openly tell Brandt that the United States was not enthusiastic about his Eastern policy. ${ }^{8}$ In addition, Nixon and other American politicians accused Brandt of being overly addicted to alcohol, which, at least in the years when Brandt was in the position of chancellor, was not true.

During the conversation between Nixon and Brandt in Florida, in December 1971, all the controversy of the American policy towards the German chancellor was shown. On the one hand, Nixon benefited from Brandt's rapprochement with Brezhnev because he was able to learn from Brandt some important characteristics of the Soviet leader, which would otherwise have remained unknown to him. On the other hand, Nixon openly told Brandt that the United States does not support his policy, but that the Federal Republic of Germany has the right to choose the methods, means and degree of responsibility (Merseburger, 2002: 624).

Of course, the position expressed in this way was not sincere, because the Americans were aware of their possibilities to control and to correct FR Germany in its foreign policy efforts. However, over time, the Americans still had to accept Brandt's initiatives, because they became prisoners of their own logic. Namely, the US policy in relations with the USSR and the Warsaw Pact during all the decades after the Second World War was primarily reflected in the constant intention to accuse the "other side" (Warsaw Pact) of not responding adequately to "cordial peace efforts", which the US reportedly constantly encouraged. In the situation when Brandt initiated such obvious peace moves, the United

8 These Nixon statements were recorded on tape, as was everything that was said in the White House. They did not become available to researchers until January 2000 (Merseburger, 2002: 626).
States could not openly oppose the policy which, in essence, was the deepening, that is, the actual realisation of their proclaimed policy. They simply had no choice, and Brandt quite consciously played that card. After signing the Berlin Agreement, the United States found itself firmly on the "Ostpolitik" line in the next negotiations with the USSR on disarmament.

However, the hidden hostility towards Brandt still remained present in Washington. Some of his old American friends from the common Berlin days also turned against Brandt, first of all General Lucius D. Clay, John J. McCloy and Dean Acheson. They thought that the story of cooperation with Moscow was pure madness (Merseburger, 2002: 625). But even after 1972, Richard Nixon was the main American opponent of Brandt's policy. In his exaggerated critiques of the new West German course, he went so far that Kissinger himself was astonished. When, in March 1973, a former US major, Hans Knabe, then an ultra-conservative columnist for the widely read "Welt am Sonntag" magazine and a major enemy of Brandt's policy, sent a letter to Kissinger condemning Brandt for alleged anti-American behaviour, the US Secretary of State did not even comment on the fanatical assessments, but his president suggested to him that Knabe "analysed things brilliantly and came very close to an actual assessment of the situation." (Merseburger, 2002: 625).

A new significant obstacle to the objectivity of Nixon's assessments during 1973 was the flare-up of the Watergate affair ${ }^{9}$ (Kissinger, 1999: 672). That was the beginning of Nixon's political downfall, which would culminate in his resignation as president in July 1974. Because of that affair, he was constantly under pressure, and he was prone to paranoid conspiracy theories, which were allegedly

9 More about the Watergate affair at URL: https:// en.wikipedia.org/wiki/Watergate_scandal. 
forged against him and the United States by both American enemies and American allies.

The new meeting between Brandt and Nixon was followed by the visit of the West German Chancellor to Washington in May 1973, immediately after Brandt's trip to Yugoslavia, and Brezhnev's visit to FR Germany. And a new round of conversation was marked by Nixon's cold performance. The American president was obviously not satisfied with the enlargement of the European Economic Community, that is, with the new possibilities that were indicated with the strengthening of European unity. In conversations with Bran$\mathrm{dt}$, he persistently avoided using the word Europe at all, even though Henry Kissinger acted differently, and proclaimed 1973 as the "Year of Europe" (Merseburger, 2002: 680).

There, more than ever before, huge differences between the American and West German conceptions of the concept of Europe were shown. The Americans expected the European concept to be subordinated to NATO in any case. Brandt openly refused that the concept, no matter how early it was at the time, be subordinated to US interests, and limited only to a regional function. ${ }^{10}$ In that sense, Brandt's visions at the time coin-

10 The attitude of some German politicians towards the politics of the great powers is shown by the conversation between Herbert Wehner, a member of the SPD Presidency and the head of the SPD Faction in the Bundestag, with Kiro Gligorov, during which Wehner spoke with great criticism and indignation FR Germany must come to terms with this. "Although we participate in a funeral called NATO and have foreign troops in the country, which gives certain limits to our activity, we cannot accept that all other countries should watch from the gallery, even though it is about their vital interests. I hope that one day "Schwarzkünstler" (Black Artist) Kissinger will break both legs by wandering around the world, touring six countries in two days and offering everyone "salvific" solutions. "Archives of Serbia and Montenegro, Fund No. 507 / IX, fas. No. 9, A.CK SKJ IX 87 / II-248, Report on the visit of the SKJ delegation to the Social Democratic Party of Germany from 12 to 15 December 1973, p. 5 cided with the political development of the European Union in the first decade of the $21^{\text {st }}$ century, i.e. about 30 years later. In conversations with Nixon, Brandt insisted on the terms "emancipated friendship" and "shared responsibility for the development of world politics" (Merseburger, 2002: 680). However, Nixon and Kissinger insisted on the political reality of the plurality of European states and their interests.

A special chapter in the talks in Washington was the upcoming crisis in the Middle East. In a conversation with Tito in April 1973, Brandt learned almost everything about the Arab preparations for war against Israel. A possible new war posed a great danger to the stability of the world economy, especially since the Middle East was home to 65 percent of the world's oil reserves. Brandt also talked about these problems with Brezhnev, so he conveyed to Nixon and Kissinger the readiness of the USSR to influence the Arabs, about lowering tensions. He also stressed the need for the United States to immediately act strongly in the context of peace mediation, so that the two world powers can show how they can solve the problem together.

The American president and the foreign minister resolutely rejected Brandt's proposals. (Merseburger, 2002: 680). They thought that such an approach would, in fact, call on the USSR to expand its zone of influence, and that is exactly what they were trying to prevent. That is why Nixon pointed out that the United States will solve that problem on its own. That was basically Kissinger's tactic. He devised mechanisms by which the Soviets would keep their distance while the Americans would at the same time consolidate themselves as the only mediators between Israel and the Arab states. As an argument for such an approach, Kissinger always highlighted the strength of the already existing American influence on 
Israel (Kissinger, 1999: 656). The opinion of Israeli Prime Minister Golda Meir was similar, when, a few days later, Brandt visited her in Tel Aviv (Merseburger, 2002: 681).

Thus, it turned out that Brandt was in no way able to influence the Americans to mediate in the Middle East conflict in a way that was in line with his overall peace visions. On the example of the Middle East, the West German Chancellor had the opportunity to realise the very real limits of his peace policy, i.e. to understand that his thesis about how the policy of European concession, which he successfully initiated and led over the previous three years, will soon lead to universal world concessions. Namely, he thought that the peace initiative could act as a war, that is, like a crisis, and that such an initiative could be easily transmitted from state to state and from region to region (Merseburger, 2002: 681). In that sense, Brandt quite obviously failed to notice how he overestimated his maneuverability. Relations with the US had not moved forward.

However, Brandt himself was careful not to put relations with the leading Western power too much to the test. Among other things, during the biggest wave of the American bombing of North Vietnam, in 1973, when almost all countries criticised the United States for excessive use of force, and when demands for American withdrawal became louder, Brandt did not touch on that topic in his public appearances. Kissinger therefore recommended that Egon Barr tell Brandt that US President Nixon found such behaviour very sympathetic, and that he was very pleased about it. (Merseburger, 2002: 670).

However, the Americans did not hesitate to show Brandt at every opportunity where the real place of the Federal Republic of Germany was within the framework of the NATO pact and the then world order. This was espe- cially evident at the time of the outbreak of the Arab-Israeli war, in October $1973 .{ }^{11}$ Given that the beginning of the war brought defeats to Israel, and even a threat to the continued existence of the Jewish state, Nixon decided to teach Europeans the right lesson about the division of labour between global responsibility and local interests. Of course, he sought to show that only Americans in the West are responsible for global responsibility. The United States immediately put all its troops deployed around the world in a higher degree of combat readiness, because Nixon feared that the USSR could invade the Suez Canal. This was, of course, a completely wrong assumption, but it was even more significant that the American allies from Western Europe were not informed about everything.

FR Germany found itself in a particularly unenviable position. The Americans used its airports to transport weapons and equipment to Israel, without asking the West German authorities for their opinion, even though the Federal Republic of Germany had been a full member of NATO since 1955. Nixon was fully conscious of showing how the United States treats Germany in this situation as its colony. The Americans used the port of Bremerhaven, the central American supply base in Europe, especially intensively, where they freely loaded weapons on ships under the Israeli flag (Merseburger, 2002: 684-685).

The Ministry of Foreign Affairs of the Federal Republic of Germany therefore sent an official protest to the United States, and the West German government, like other European governments, officially took a neutral stance towards the war in the Middle East. Washington responded angrily to these moves by persuading Bonn and other

11 It was the so-called Yom Kippur War, the fourth total war between the Arab states and Israel, after the creation of the Jewish state in 1948. 
Europeans to cowardly capitulate to the oil blackmail of the Arabs, and that there would be a catastrophe if the West showed weakness before the not very dangerous military action of the Arabs, supported by the Soviets. Brandt learned that many West German diplomats were told by the Americans that "from an American perspective, FR Germany has only limited sovereignty and that the United States reserves the right to resort to measures that seem appropriate or necessary in the interests of international security" (Merseburger, 2002: 685). That is why Brandt hurried to send a letter of support to Nixon for his policy in the Middle East. However, he received only a superficial answer from the American president that the United States would consider consulting FR Germany in similar actions in the future, but that the Middle East issue should not be separated from NATO's global policy, especially since the United States considered the USSR very involved in the story of the Arab-Israeli conflict (Hobsbaum, 2002: 187).

Kissinger also joined Nixon in criticising Brandt's stance during the 1973 Middle East war. He blamed the chancellor for betraying the solidarity he himself had offered Israel during a visit to Golda Meir in June 1973. ${ }^{12}$ Faced with growing pressure, Brandt was forced to send an electronic device of exceptional combat importance to Israel, despite German laws banning arms deliveries to warring zones. ${ }^{13}$ (Merseburger, 2002: 686).

12 It was here, obviously, that the great strength of the Jewish lobby in the United States came to the fore, in which Kissinger himself was one of the main bearers.

13 To date, it has not been clearly established what kind of device it was, because Brant did everything to cover up that delivery. It was probably a technologically advanced radar station, developed by the West German army (Bundeswehr). That radar station could accurately register air activity within a radius of about 500 kilometers, which was a major technological breakthrough at the time. Some members of the West German government who were involved in the
Only after that delivery did the attacks of the American-Jewish public on Brandt stop.

However, then, problems with the Arab boycott of oil trade with the West came to the fore. Brandt was then again put in the unwanted situation of having to choose between the US and France. There was a paradoxical situation - although the Americans were traditionally against the emphasis on European unity and a unified European policy, in the new situation they demanded that Europeans take a common stand against the Arab boycott at the February 1974 oil consumer conference in Washington to weaken pressure on US oil reserves, and jointly more easily forced the Arabs to change course. The French had other plans. They wanted everyone to negotiate with the Arabs separately. Nixon sent an ultimate request for joint action or else threatening the withdrawal of American security guarantees for the whole of Europe. Again, primarily because of West Berlin's still sensitive position, Brandt had to obey Nixon's demands. That is why the German Minister Helmut Schmidt in Washington accepted the American conditions, which led to new problems in the relations between the Federal Republic of Germany and France (Merseburger, 2002: 686-688).

With the troubles in relations with the United States and France, the only foreign policy satisfaction for Brandt was reflected in the complete triumph of Eastern policy in 1973. In addition to the final ratification of all peace treaties, a major peace conference began in Helsinki in July 1973. The foreign ministers of 33 European countries, as well as the United States and Canada, gathered there. Within this complex peace process, arms

transaction later only confirmed that it was a supply of equipment that was absolutely decisive for the war. All these details were first discovered only in 2000 by the journalist of "Zeit" ("Die Zeit") magazine, Klaus Harprecht (Merseburger, 2002: 686). 
reduction negotiations took place between 12 NATO countries and seven Warsaw Pact countries, which began in Vienna at the end of October of the same year (Merseburger, 2002: 689).

Even Nixon paid tribute to the efforts of the Federal Republic of Germany during the last meeting with Brandt, in Washington, September 1973, when the West German Chancellor came to the United Nations session, to give a speech after both German states were admitted to that organisation. On that occasion, Brandt pointed out that despite the existence of two states, the Germans still form one nation, and that the Federal Republic of Germany will continue to work wholeheartedly on German unification (Merseburger, 2002: 689).

\section{CONFRONTATIONS OF WILLY BRANDT AND AMERICAN POLITICS AFTER 1974}

In any case, the United States did not help Will Brandt much in terms of implementing the policy of German unification, because that unification and drastic change of European political balance in terms of further significant strengthening of Germany in the early 1970s did not suit them at all. Throughout Brandt's tenure, US attitudes toward his Eastern policy were overwhelmingly suspicious. Distrust was pronounced, and at certain moments American threats and ultimatums were so direct that it became clear how inaccurate all the stories about the harmonious and equal development of NATO and the alleged harmony of the United States and its Western European allies were, and how the United States at that moment was careful to maintain its leading role in the alliance firmly and uncompromisingly.

President Nixon himself played a major role in such an American approach, showing little tact in dealing with the Allies, and was particularly intolerant of Brandt's attempts to secure greater independence for West German politics. The almost simultaneous departure of Brandt and Nixon from the positions of political leaders of their countries, in 1974, showed how fundamentally different the perception of their achievements was in the world public. Through his work, Brandt left the impression of a man who sincerely wanted the development of peace initiatives and equality, which enabled him to enjoy the reputation of a respectable world peace judge, whose word was listened to and respected, in the following years, until his death in 1992. Only his withdrawal from the position of West German Chancellor on May 6, 1974 , caused a real flood of positive reactions from the American press, which claimed that "the great politician left the scene with style" (Merseburger, 2002: 730). At the time, leading figures in American journalism, James Reston and Anthony Lewis, said that Brandt's act of resignation was proof of his moral superiority and political greatness. Lewis paid particular attention to how much better Brandt proved to be than Nixon, both as a man and as a politician (Seebacher, 2006: 279). Unlike Brandt, Nixon left the political scene with insults and mortgages of political affairs, and never again represented a relevant factor in American and world politics.

Even after his resignation, Brandt had certain disagreements with American politics. As early as 1975, there was a danger of American intervention in Portugal, because in the United States, Kissinger and other politicians believed that Portugal would become the first socialist country in Western Europe after the democratic revolution, and that the influence of the USSR in that country would become dominant ${ }^{14}$ (Görtemaker, 1999: 589; Kissinger,

14 However, it is not disputed that there was a certain 
1999: 678-679).

Thanks to good relations with the leader of the Portuguese Socialists, Mario Soares, and his earlier contacts with Brezhnev, Brandt successfully mediated in Portuguese political circles and the USSR, and prevented the coup, which the Communists in Portugal planned to implement in November 1975. Soares, then, in April 1976, became Portugal's first socialist prime minister, and the Americans lost the opportunity for another demonstration of force in Europe.

Further confrontations continued after Brandt became president of the Socialist International in 1976. When, after a short time spent by Democrats in power in the US, Republican candidate Ronald Reagan came to the presidency in early 1981, the US again shifted the bow of its foreign policy toward conservatism (Hobsbaum, 2002: 190). At that time, Brandt, who, despite his pragmatism, remained an outspoken socialist, did not hesitate to openly say that he was closer to Soviet policy than to Reagan's ambitious Star Wars ${ }^{15}$ armed programme, which became a new threat to world peace (Merseburger, 2002: 805).

Brandt did not even react to the statement of the American president Ronald Reagan given in Washington in 1986, in which he emphasised that if he was the president

new Soviet political offensive in 1974. Encouraged by the American difficulties due to the "Watergate" affair, and the withdrawal of US troops from Vietnam, the Soviets sought, primarily through cooperation with Cuba, to expand their influence in countries where there were prospects for communist revolutions. So, they operated in Portugal, and then in Angola, Mozambique, Somalia, Yemen, and the Caribbean.

15 This American combat concept was named after the famous science fiction film of the same name, and was based on an enormous investment in war satellites, which were to serve as a means of defense against a possible Soviet intercontinental ballistic attack on the United States, but also as a means of attack, through so-called laser transfer. when the Soviets erected the Berlin Wall, he would tear it down. When asked by journalists to comment on that, Brandt did not react, noting in his autobiography that these were only strong and provocative words of the American president, intended for Gorbachev at that very moment. (Brandt, 1992: 45).

The fall of the Berlin Wall on November 9, 1989, and German unification a year later were interpreted by Brandt not only as a triumph over the communist ideology of isolation, to which he had contributed twenty years earlier, but also as a triumph over American attempts to prevent more independent politics of FR Germany.

\section{CONCLUSION}

As the Melting Point of the Cold War and the "Schaufenster der freien Welt", Berlin was the most suitable location for events, processes and policies that would not make as much sense anywhere else. Within this context, the cooperation of the American occupation authorities with the young liberal Social Democrat, Willy Brandt, once an ardent leftist and his associates, was neither strange nor unexpected. It cannot be said that there was much love among them, sometimes not even respect, but there was much practicality and ultimately results that brought benefit to the citizens of Berlin and Germany. The evolution of mutual relations took place within interdependence of the Cold War atmosphere, sometimes flashing with the appearance of the celebrity of the American president, Kennedy, only to sink again into tension and muscle showing, which was emphasised by President Nixon. For several decades, Willy Brandt successfully coped with the challenges of West German and inter-German political relations, cooperating with the Americans, garnishing it with escapades of hedonism 
while associating with Eastern European communist masters, such as Brezhnev and Tito. He had the freedom to act as much as the American patrons allowed him, that is, as long as the cooperation with Brandt was useful to them and did not trouble them. On the other hand, until the elections for the position of the mayor of Berlin, and even until he took over the chancellor's position, Brandt allowed his political path to be largely defined by American influence. However, a marriage of convenience left its mark on the most popular star of West Germany during the Cold War, both professionally and personally. Sobering up and political decline followed in moments of greatest popularity and glory. Whether Willy Brandt was too relaxed, overly open, too liberal, or politically careless ultimately doesn't matter, Americans didn't need him like they did twenty-five years earlier.

\section{REFERENCE}

Arhiv Srbije i Crne Gore, Fond br.507/IX, fas. br.9, A.CK SKJ IX 87/II-248, Izveštaj o poseti delegacije SKJ Socijaldemokratskoj partiji Nemačke u vremenu od 12. do 15. decembra 1973. godine, стр. 5 .

Bahr, E. (1996). Zu meiner Zeit. München: Blessing

Bender, P. (1995). Die neue Ostpoltik und ihre Folgen. Vom Mauerbau bis zur Vereinigung. München: Deutscher Taschenbuch Verlag

Brandt, W. (1982). Links und frei - Mein Weg 1930-1950. Hamburg: Hoffmann und Campe Verlag

Brandt, W. (1992). My Life in Politics. New York: Viking Adult
Göbel, W. (1996). Abiturwissen Deutschland nach 1945. Stuttgart-Desden: Klett

Görtemaker, M. (1999). Geschichte der Bundesrepublik Deutschland. Von der Gründung bis zur Gegenwart. München: Beck

Hobsbaum, E. (2002). Doba Ekstrema. Istorija Kratkog dvadesetog veka. Beograd: Dereta

Kisindžer, H. (1999). Diplomatija II. Beograd: Verzal press

Kissinger, H. (1981). Memoari I-II. Zagreb: Vjesnikova press agencija

Koch, P. (1988). Willy Brandt. Eine politische Biographie. Berlin: Ullstein

Krause, S. (2015). Neue Westpolitik: The Clandestine Campaign to Westernize the SPD in Cold War Berlin, 1948-1958. Central European History, 48(1), 79-99. Published online by Cambridge University Press: 29 April 2015. Retrived 22.03.2020. URL: https://www.cambridge.org/core/ journals/central-european-history/article/ neue-westpolitik-the-clandestine-campaign-to-westernize-the-spd-in-cold-war-berlin-19481958/52 F67 754F556 B 08 E BE952E0FF14B9BBE

Merseburger, P. (2002). Willy Brandt 19131992. Visionär und Realist. Stuttgart-München: Deutsche Verlags-Anstal

Michel, J. (2010). Willy Brandts Amerikabild und -politik 1933-1992. Göttingen: V\&R unipress

Münkel, D. (2004). Als „deutscher Kennedy“ zum Sieg? Willy Brandt, die USA und die Medien. Zeithistorische Forschungen/Stu- 
dies in Contemporary History, Online-Au- Seebacher, B. (2006). Willy Brandt. München: sgabe, 1, H. 2. Retrived 14.03.2020. URL: Piper Verlag http://www.zeithistorische-forschungen. de/16126041-Muenkel-2-2004

Document number CIA-RDP80B01676R003200180020-8. Retrived 12. 03. 2020. URL: https://archive.org/details/ cia-collection (12.03.2020.) 


\section{ШАРМАНТНИ НИЈЕМАЦ У РАЉАМА АМЕРИЧКЕ ПОЛИТИКЕ Утицај САД на политичко профилисање и Источну политику Вилија Бранта}

Кључне ријечи:

Вили Брант; Сједиюене Америчке Државе; Источна политика; Џон Ф. Кенеди; Ричард Никсон; Хенри Кисиниер

Аутор:

Др Славојка БештићБронза је доцент на Филозофском факултету Универзитета у Баноо Луции

Коресподенција:

slavojka.bestic-bronza@ ff.unibl.org

Област:

Опита историја

\section{Резиме}

Циљ овог рада је да покаже у коликој мјери и којим механизмима су САД утииале на политичко формирағе личности и дјелатности западнонемачког каниелара Вилија Бранта. Посебан акценат је ставтен на америчке утицаје током провођена Брантовог најпознатијег политичког концепта, „Источне политике“, који се ставла хронолошки контекст развоја односа у складу са општеевропским и свјетском политичким кретатима, и юиховој корелацији са Брантовим политичким путем у егзилу и касније у, од стране Савезника окупираној Њемачкој, а потом и новоствореној независној Савезној Републици Њемачкој. Околности, личне (не)склоности и међусобни утицаји су изродили један прилично амбивалентан однос, настао у највећој мјери због интереса једне и друге стране, који су се у одређеним временским периодима преклапали, док су се касније удалавали и постајали хладни, често и непријательски.

DOI:

10.5937/politeia0-26956

Датум пријема чланка:

21.03.2020.

Датум прихватања

чланка за објављивање:

07.06.2020 
